\title{
Isolation and characterization of micro satellites in Bambusa arundinacea and cross species amplification in other bamboos
}

\author{
SUMITRA NAYAK and GYANA RANJAN ROUT* \\ Plant Biotechnology Division, Regional Plant Resource Center, Nayapalli, Bhubaneswar -751 015, Orissa, India \\ Accepted January 15, 2005

\begin{abstract}
Isolation and characterization of microsatellites was analyzed in Bambusa arundinacea and cross species amplification in other bamboos. Six microsatellites, three polymorphic and three monomorphic, were characterized in a bamboo species, Bambusa aruninacea belonging to the family Poaceae. The numbers of alleles per locus ranges form 2 to 6 . Allelic diversity ranges from 0.128 to 0.789 . Polymorphic Information Content (PIC) values for two loci were $>\mathbf{0 . 3}$, as an indicator of polymorphic allele. Cross species amplification has been tested in other 18 bamboo species. Monomorphic simple sequence repeats (SSRs) have been found to be cross amplified in most of the tested species while polymorphic ones in only three to four species. Utilization of the SSR loci in genetic diversity study of
\end{abstract} \\ $B$. arundinacea and other cross amplified bamboo species is discussed.
}

Key words: Bambusa arundinacea, microsatellite marker, cross species amplification, population study, species identification.

\section{INTRODUCTION}

Bamboos, a group of arborescent grasses, have closely been associated with mankind since ancient time. They are used for a variety of purposes such as mat making, traditional instruments, furniture, musical instruments, flooring and construction materials, paper making, fencing, fodder, fuel wood, cooking utensils, floats for timber and rafts, sericulture industry, and waste water management. They belong to family Poaceae subfamily Bambusoideae. They have one of the widest habitats with more than 1500 species thriving in every continent but the poles. They are found mostly in tropical and subtropical regions. These are just grasses but vary in height from dwarf, one foot $(30 \mathrm{~cm})$ plant to giant timbers that can grow to $100 \mathrm{ft}$ (40 meters). Bamboo flowers irregularly and usually at very long time interval of 30 to 120 years, and when it does it takes so much of energy

\footnotetext{
*Correspondence author. E-mail: grrout@hotmail.com.
}

from the plant that it often dies. So, they are generally clonally propagated with occasional propagation from seeds (http://www.americanbamboo.org/). Genetic/genotypic diversity may be more in the natural bamboo growing region due to occasional flowering. Out of the different type of DNA marker systems available for genetic diversity study microsatellites are proved to be the best one. Microsatellites also known as simple sequence repeats (SSR), are short tandemly repeated sequence motifs consisting of a repeat unit of $1-6$ bp in length (Tautz and Schlötterer, 1994). They are highly polymorphic DNA markers with discrete loci and codominant alleles. Microsatellites are currently the marker of choice for genome mapping (Brondani et al., 2002; Sharopova et al., 2002), population genetic analysis, (Mariette et al., 2002, Dutech et al., 2002), genetic diversity study (Kisuki and Isagi, 2002), cultivar and variety identification (Cantini et al., 2001; Faria et al., 2000), and evolutionary genetics because of their ubiquitous and uniform distribution within both eukaryotic and prokaryotic (Field and Wills, 1996). Microsatellites 
are also characterized with high information content, ease of genotyping through PCR, high discrimination power and high degree of allelic variability which is presumably caused by a high mutation rate and replication strand slippage that changes microsatellite array length.

Microsatellites have been used in a number of plant species for construction of genetic linkage map (Brondani et al., 2001; Sharopova et al., 2002), quantitative trait loci mapping (Liu et al., 2002), and gene tagging (Kim et al., 2002, Xie et al., 2001). These microsatellites need to be isolated de novo from the species or from the most related species that are being examined for the first time (Zane et al., 2001). Microsatellites have been identified in a number of economically important pant species such as maize, sunflower, avena, eucalyptus, barley, grape, rice, and chestnut (Sharopova et al., 2002; Paniego, 2002; Li et al., 2000; Glaubitz et al., 2001; Ramsay et al., 2000; Lefort et al., 2002; McCouch, 1997; Marinoni et al., 2003). In clonally propagated crops, microsatellites have been used for cultivar identification, population genetic structure and genetic diversity study. Here, we report the isolation and characterization of microsatellites in Bambusa species.

\section{MATERIALS AND METHODS}

\section{Plant materials}

Leaf samples of Bambusa arundinacea Willd were collected from 15 different clumps arbitrarily from Regional Plant Resource Center, Bhubaneswar forest area. Care was taken to collect samples from the clumps with at least 100 meters away from the nearby clump. Leaf samples of other bamboos including Dendrocalamus giganteus Munro, D. strictus Nees, Dinochlea mclellandii Kurtz, Cephalostachyum pergracil Munro, Bambusa vulgaris Schr, $B$. vulgaris var striata Schr, B. nana Roxb., B. multiplex Raeush, $B$. balcooa Roxb, B. ventricosa and Sasa sp. Makino and Shibata were collected from the Bambusetum of Regional Plant Resource Centre, Bhubaneswar. Leaf samples of other bamboo species such as Arundinaria mannii Gamble, Dendrocalamus sikkimensis Gamble, $D$. hookeri Munro, D. hamiltoni Nees and Arn, D. patellaris Gamble, Bambusa tulda Roxb., B. nutans Wall ex Munro, and $B$. clarata were collected from Sikkim, one of the treasure house of Himalayan bamboos.

\section{DNA extraction}

DNA was extracted from semi mature fresh/frozen/dried/semidried leaves following the $\mathrm{N}$-cetyl-N,N,N-trimethyl ammonium bromide (CTAB) method of Doyle and Doyle (1990) with little modification, as the leaves of bamboos contain silica materials. $2.5 \mathrm{~g}$ of leaf material was surface sterilized by wiping with $80 \%$ ethanol, then cut into small pieces and ground into fine powder using liquid nitrogen. $10 \mathrm{ml}$ of preheated extraction buffer [100 mM Tris- $\mathrm{HCl}(\mathrm{pH} 8.0), 2$ $\mathrm{mM}$ EDTA, 3\% CTAB (w/v), 0.2\% $\beta$-mercaptoethanol (v/v), $1.4 \mathrm{M}$ $\mathrm{NaCl}$ ] was added to the powder and incubated for at least $2 \mathrm{~h}$ at $60^{\circ} \mathrm{C}$ with little mixing at every $15 \mathrm{~min}$ interval. After several standard steps, the pellet was washed with $70 \%$ ethanol and dissolved in 200-300 $\mu \mathrm{l}$ of TE (10 mM Tris pH 8.0, $1 \mathrm{mM}$ EDTA). DNA quantification was made by visualizing under UV light against a $\lambda$ DNA uncut marker after electrophoresis on $0.8 \%(w / v)$ agarose gel containing $0.5 \mu \mathrm{g} \mathrm{ml}^{-1}$ of ethidium bromide.

\section{Library construction}

$20 \mathrm{~g}$ of extracted DNA (only from one individual) was completely digested with $\mathrm{Mbol}$ (GIBCO BRL, USA). The digested DNA was concentrated (ethanol precipitation), dissolved in $30 \mu \mathrm{l}$ of TE and electrophoresed on a $1 \%$ low melting agarose gel (GIBCO BRL, USA) along with molecular weight markers (MBI fermentas, USA). DNA fragments corresponding to 350 to $550 \mathrm{bp}$ were excised from the gel and purified with QIAquick gel extraction kit (QIAGEN). Ligation reaction was performed with $50 \mathrm{ng}$ of gel purified insert DNA and $100 \mathrm{ng}$ of dephosphorylated pUC19/BamHI (Bangalore Genei, India) plasmid DNA (vector: insert $=1: 4$ ) and $1 \mu$ of T4 DNA ligase (GIBCO BRL, USA) in a total volume of $20 \mu \mathrm{l}$ at $16^{\circ} \mathrm{C}$ for overnight. Ligated products were transformed into $\mathrm{DH} 5 \alpha$ competent cells and transformants plated on $82 \mathrm{~mm}$ LB/ampicilin plates with Xgal and IPTG for blue white screening.

\section{Screening for microsatellite repeat sequences}

All the white colonies were transferred onto LB/ampicillin plates with the help of sterile tooth picks and incubated for another $12 \mathrm{~h}$ at $37^{\circ} \mathrm{C}$ by putting nylon membranes (Hybond $\mathrm{N}+$, Amersham Pharmacia) over the plates. Then the membranes were lifted out of the plates, air dried and processed by placing colonies side up in a petri dish containing sterile paper soaked with (a) 10\% SDS for 3 $\min$; (b) $1.5 \mathrm{M} \mathrm{NaCl} / 0.5 \mathrm{~N} \mathrm{NaOH}$ (Fresh) for 5-10 min; (c) $1.5 \mathrm{M}$ $\mathrm{NaCl} / 0.5 \mathrm{MTris}(\mathrm{pH} 7.8$ ) for 5-10 min; (d) $2 x$ SSC for 1 minute. Crosslinking of the DNA on nylon membrane was done in a UV cross linker (Hoefer, Amersham Pharmacia). The probe, (GT) 15, used to screen the library, was 3'end labeled with the help of DIG oligonucleotide tailing kit (Roche) following manufacturer's instruction. Oligonucleotide was enzymatically labeled at their 3' end with terminal transferase by incorporation of digoxigeninlabelled deoxyuridine triphosphate (DIG-dUTP/dATP) tail. Prehybridization was done by incubating the blots with shaking at $65^{\circ} \mathrm{C}$ in appropriate amount of pre-hybridization buffer (5X SSC, $0.5 \%$ SDS, $0.1 \mathrm{mg} / \mathrm{ml}$, and $0.1 \%$ lactogen) in polythene bags for $1 \mathrm{~h}$. Hybrididization was done at $68^{\circ} \mathrm{C}$ overnight in the same prehybridization solution with labeled probe. Positive clones were detected colorimetrically, inoculated in $2 \mathrm{ml}$ of BL/amp and grown overnight. Next day $1 \mathrm{ml}$ of the above culture was stored in $-80^{\circ} \mathrm{C}$ with $15 \%$ glycerol for further use and plasmid DNA was isolated from rest $1 \mathrm{ml}$ of culture (Sambrook et al., 1989). The above positive clones were reconfirmed through dot blot.

\section{SSR polymorphism}

Positive clones were sequenced by an automated sequencing facility. Oligo primers were designed from the flanking regions of identified repeats using primer select module of DNASTAR software and synthesized by MWG-Biotech AG (Germany). For PCR genotyping of microsatellites, amplification was carried out in a final volume of $25 \mu \mathrm{l}$ containing $10 \mathrm{mM}$ Tris- $\mathrm{HCl}, \mathrm{pH} 9.0 ; 50 \mathrm{mM} \mathrm{KCl}$; $0.01 \%$ gelatin; $1.5 \mathrm{mM} \mathrm{MgCl}$; 5 pmole of each primer; $200 \mu \mathrm{M}$ dNTPs; 0.25 units of Taq DNA polymerase (Bangalore Genei, India); and $20 \mathrm{ng}$ genomic DNA. Amplifications were performed in a PTC 100 thermocycler (MJ research, USA) programmed for initial denaturation of $4 \mathrm{~min}$ at $94^{\circ} \mathrm{C}$ followed by 25 cycles of $1 \mathrm{~min}$. at $94^{\circ} \mathrm{C}, 2 \mathrm{~min}$. at annealing temperature (Table 1) and $2 \mathrm{~min}$ at $72^{\circ} \mathrm{C}$. A final extension of $7 \mathrm{~min}$ at $72^{\circ} \mathrm{C}$ and indefinite halt at $4^{\circ} \mathrm{C}$. Amplified products were dried on a vacuum concentrator (DNA 
Table 1. Microsatellite loci identified from the genome of $B$. arundinacea with GenBank Accession number, primer sequence, annealing temperature and expected fragment size.

\begin{tabular}{|c|c|c|c|c|c|c|}
\hline Locus & Repeat sequence & $\begin{array}{l}\text { GenBank } \\
\text { Accession } \\
\text { number }\end{array}$ & Primer sequence (5'-3') & $\begin{array}{l}\text { Expected } \\
\text { PCR product } \\
\text { (bp) }\end{array}$ & $\begin{array}{l}\text { Annealing } \\
\text { temp. Tm }\end{array}$ & $\begin{array}{l}\text { Amplification } \\
\text { status }\end{array}$ \\
\hline Ba10 & (GT) $12 \mathrm{C}(\mathrm{TA}) 10$ & AJ507486 & $\begin{array}{l}\text { F-GGTGGGGTCTAGCACCTAAG } \\
\text { R-TACCAGCATGTAACGGTCGG }\end{array}$ & 146 & $60^{\circ} \mathrm{C}$ & Amplified \\
\hline Ba14 & (CA) 10 & AJ507487 & $\begin{array}{l}\text { F-AGAGTTAAGGAAGCCAGGTC } \\
\text { R-GTCTAGTAGCTGCTCAACTC }\end{array}$ & 237 & $57^{\circ} \mathrm{C}$ & Amplified \\
\hline Ba18a & (CT) $5 n(C T) 5$ & AJ507488 & $\begin{array}{l}\text { F-TATCTCGACCTCCCCTTGCT } \\
\text { R-GTCTAGAAGCAGGGAGGTAG }\end{array}$ & 166 & $59^{\circ} \mathrm{C}$ & Amplified \\
\hline Ba18b & $(\mathrm{CA}) 13$ & AJ507488 & $\begin{array}{l}\text { F-CCAGGTCGTTTCACTGCTC } \\
\text { R-ACAACGGTAGAGTTCACTCG }\end{array}$ & 146 & $57^{\circ} \mathrm{C}$ & Amplified \\
\hline Ba20 & (AC)31(AT)7 & AJ507489 & $\begin{array}{l}\text { F-TTGATTGCCCTACTCTGTCG } \\
\text { R-TCAACGGTGGATGACCTAGG }\end{array}$ & 169 & $57^{\circ} \mathrm{C}$ & Amplified \\
\hline Ba25 & $\begin{array}{l}\text { (GACA)3(GATA)2 } \\
\text { GAT(GATA)1 }\end{array}$ & AJ507490 & $\begin{array}{l}\text { F-GTGAGATGGGCTGGGCAG } \\
\text { R-GCTCCGATCTGTCAGTTTAC }\end{array}$ & 242 & $57^{\circ} \mathrm{C}$ & Not amplified \\
\hline Ba58 & $(\mathrm{CA}) 7$ & AJ507491 & $\begin{array}{l}\text { F-TCCGAAGCACACTCATGAAG } \\
\text { R-TTCTACTATGCGCTAACTGC }\end{array}$ & 187 & $55^{\circ} \mathrm{C}$ & Amplified \\
\hline Ba202 & $\begin{array}{l}\text { (AC)3C(AC)2GC(A } \\
\mathrm{C}) 4\end{array}$ & AJ507492 & $\begin{array}{l}\text { F-CAACTAGCAAACGCACAGTG } \\
\text { R-CGAATTCGAGCTCGGTACC }\end{array}$ & 261 & $57^{\circ} \mathrm{C}$ & Not amplified \\
\hline
\end{tabular}

plus), mixed with $10 \mu \mathrm{l}$ of formamide loading dye, heat denatured and then separated on $8 \%$ denaturing polyacrylamide gel with $7 \mathrm{M}$ urea and 0.5X TBE. Separation was performed on vertical gel electrophoresis (Hoofer SE 600) at a constant current of 20 watt for about 2 h. 100 bp ladder of MBI Fermentas was used as a size standard. Detection of the amplification products was done by silver staining (Riesner et al., 1989). After initial fixation in a $10 \%$ ethanol $/ 0.5 \%$ acetic acid solution for $10 \mathrm{~min}$ the gels were immersed for $15 \mathrm{~min}$ in a fresh $5.9 \mathrm{mM}$ solution of silver nitrate, and developed for $10 \mathrm{~min}$ in $375 \mathrm{mM} \mathrm{NaOH}, 2.3 \mathrm{mM} \mathrm{NaBH} 4$ and $0.125 \%$ formaldehyde $(37 \%, w / v)$.

\section{Data analysis}

For each locus, genotpypes, total number of allele, allele frequencies and observed heterozygosity (ho) were determined from the gel. Expected heterozygosity (he), the proportion of expected heterozygotes under random mating condition, was calculated according to Nei (1987). Inbreeding coefficient (fis), a measure of heterozygosity deficit or excess, for a particular locus was calculated according to Wright (1978). Effective number of allele (AE) for a particular locus was calculated according to Hartle and Clark (1989). A polymorphic information content (PIC) value of a locus was calculated according to Anderson et al. (1992).

\section{RESULTS}

Screening of four thousand recombinant colonies of the partial genomic library with (CA) 15 oligo resulted in 15 positive clones. Second round of screening through dot blot resulted in eleven positive clones. Out of the eleven clones sequenced seven were found to contain one or more repeat motifs of varying length. Oligo primers have been designed for eight loci of which six could be amplified (Table 1). The use of dephosphorylated pUC vectors helped in getting $100 \%$ positive white colonies in first few LB/amp plates with X-gal and IPTG. This eliminated the use of X-gal and IPTG for blue white screening of recombinants in the subsequent LB/amp plates. Second round of screening through dot blots helped in elimination of false positive which are often found through radioactive as well as non-radioactive detection systems. The first round of screening was less $(46 \%)$ than the second round of screening $(64 \%)$ in case of $B$.arundinacea. About half of the loci amplified found to be monomorphic and rest were polymorphic. Half of the amplified loci (3) found to be polymorphic and rest three were monomorphic in a panel of 15 tested individuals. The number of allele for all the polymorphic loci ranged from 2 - 6 with an average of 4.6. Loci B10 and B20 both have 6 alleles each and locus B18a have only 2 alleles. Observed heterozygosity, expected heterozygosity, fixation index and PIC values for all the polymorphic loci were presented in Table 2. PIC value was highest (0.7627) for locus Ba20 and lowest (0.1244) for Ba18a. Loci containing longer repeat units $(<20)$ were found to be more polymorphic than locus containing shorter repeat unit (Ba18a). Cross species amplification of other bamboo species by taking primers of $B$. arundinacea microsatellite loci were presented in Table 3. All the polymorphic/functional microsatellite loci amplified in 
Table 2. Number of allele, observed (ho) and expected (he) heterozygosity, effective number of allele (AE), fixation index (fis) and polymorphic information content (PIC) of the three polymorphic microsatellite loci of $B$. arundinacea.

\begin{tabular}{|l|c|c|c|c|c|c|c|}
\hline Locus name & Sample size (n) & $\begin{array}{c}\text { No. of } \\
\text { allele }\end{array}$ & ho & He & fis & AE & PIC \\
Ba10 & 14 & 6 & 0.357 & 0.736 & 0.515 & 3.787 & 0.709 \\
Ba20 & 15 & 6 & 0.200 & 0.789 & 0.746 & 4.739 & 0.762 \\
Ba18a & 15 & 2 & 0.000 & 0.128 & 1.000 & 1.4775 & 0.124 \\
\hline
\end{tabular}

Table 3. Cross species amplification $B$. arundinacea microsatellite loci in different bamboo species.

\begin{tabular}{|l|c|c|c|c|c|c|}
\hline Name of the bamboo species & Ba10 & Ba14 & Ba18a & Ba18b & Ba20 & Ba58 \\
\hline A. mannii Gamble & - & - & - & - & - & $+{ }^{* *}$ \\
B. balcooa Roxb & - & + & + & + & - & + \\
B. nana Roxb & - & + & + & + & + & $++^{*}$ \\
B. multiplex Raeush & - & + & + & + & + & $+^{*}$ \\
B. clarata & + & + & + & + & - & + \\
B. nutans wall ex Munro & - & + & + & + & - & + \\
B. vulgaris Schr & + & + & + & + & - & + \\
B. vulgaris var striata Schr & + & + & + & + & - & + \\
B. ventricosa & + & + & + & + & - & + \\
C. pergracil Munro & - & + & + & + & - & + \\
D. miclellandii Kurtz & - & + & + & - & - & + \\
D. giganteus Munro & - & + & + & + & - & + \\
D. strictus Nees & - & + & + & + & + & + \\
D. hookeri Munro & - & + & + & + & - & + \\
D. hamiltoni Nees and Arn & - & - & + & - & - & + \\
D. patellaris Gamble & - & - & - & - & - & - \\
D. sikkimensis Gamble & - & + & + & + & - & + \\
Sasa sp. Makino and Shibata & - & + & - & - & - & + \\
\hline
\end{tabular}

+ specific amplification; - no amplification;

* nonspecific amplification; ** very less amplification product.

some of the bamboo species. Locus Ba10 amplified in four other bamboo species such as $B$. clarata, $B$. vulgaris, $B$. vulgaris var striata and $B$. ventricosa. Locus Ba20 was amplified in $D$. strictus, a species belongs to genus Dendrocalamus. Nonspecific amplification of Ba20 was observed in $B$. nana and $B$. multiplex. All the three momomrphic microsatellites were amplified in almost all the tested species.

\section{DISCUSSION}

The primary objective of this study was to isolate and characterize of microsatellites in in B. arundinacea and cross species amplification in other bamboos. Screening about four thousand recombinant colonies of the partial genomic library with (CA) 15 oligo resulted in 15 positive clones. Second round of screening through dot blot resulted in eleven positive clones. Out of the eleven clones sequenced seven were found to contain one or more repeat motifs of varying length. The chance of getting a microsatellite repeat motif after first round of screening was less $(46 \%)$ than that of second round of screening (64\%) in the case of B.arundinacea. This might be true for all other bamboos. About half of the loci amplified found to be monomorphic and rest were polymorphic. This might be due to the nature of the plant itself. Being highly clonally propagated and rarely sexually propagated (self/wind pollinated) plant, there is less chance of replication slippage (Schlötterer and 
Tautz, 1992; Richards and Sutherland, 1994), a common methods for formation of alleles in microsatellite loci. Further unequal crossing over during homologous recombination in the site of microsatellite, other method of formation of allele in microsatellite loci (Jakupiak and Wells, 1999), may not be happening due to very long and erratic flowering period. Presence of imperfect repeats in most of the identified loci suggests that mutation might have played a leading role in the formation or degradation of a microsatellite locus (Zhu et al., 2000). Loci containing longer repeat units $(<20)$ whether perfect or imperfect such as Ba10 and Ba20 were found to be more polymorphic than locus containing shorter repeat unit (Ba18a). This might be due to the rate of microsatellite mutation which is directly proportional to the repeat length (Goldstein and Clark 1995; Schug et al., 1998), there by forming more alleles in a longer repeat motif. Furthermore, the rate of contraction mutations increase exponentially over repeat length and that of expansion mutations constant for all shorter and longer alleles (Xin et al., 2002). Cross species amplification of different bamboo species occured in few species. Locus Ba10 amplified in four other bamboo species (B. clarata, $B$. vulgaris , B. vulgaris var striata and B. ventricosa). Locus $\mathrm{Ba} 20$ was amplified in $D$. strictus, a species belongs to genus Dendrocalamus. Nonspecific amplification of Ba20 was observed in $B$. nana and $B$. multiplex. So, these loci may be useful for population genetic studies in the cross amplified species. However, inter specific differences in the repeat motif may be varied and influence the level of variability in the cross amplified taxon (Eustop et al., 1995).

All the three monomorphic microsatellites were amplified in almost all the tested species. These loci might be present in the transcribed region and cross amplify readily in related genera and species. Cordeiro et al. (2001) observed that the Saccharum EST (Expressed Sequence Tag) - SSRs could cross amplify readily in related genera such as Erianthus and Sorghum sp but not the Saccharum genomic region SSRs. Frequency of microsatellites in plants is higher in the transcribed region especially in the untranslated region (Morganate et al., 2002) than in the repetitive fraction (Ramsay et al., 1999). Among plant species, the overall frequency of microsatellites is inversely related to the genome size and proportion of the repetitive DNA but remained constant in the transcribed portion of the genome (Morganate et al., 2002). Homology search of bamboo SSR loci in BLAST showed no concrete similarity with any of the transcribed or EST regions. Only $20 \mathrm{bp}$ of locus $\mathrm{Ba} 18 \mathrm{a}$ is similar to (a) human $\mathrm{L} 1 \mathrm{Heg}$ repetitive element from the intergenic region of the epsilon and Ggamma globin gene and (b) human 3' end of the gene for protein tyrosine kinase phospatase receptor type $\mathrm{K}$.

In conclusion, three polymorphic microsatellite loci in $B$. arundinacea, have been identified and characterized for the first time (to our knowledge) in bamboo. These will help in population genetic study and genetic diversity study in the clonally propagated $B$. arundinace and other bamboos.

\section{ACKNOWLEDGEMENTS}

The authors wish to thank Director CIFA, Kaushalyaganga for permitting to use laboratory facilities during this work. The first author is grateful to the Council of Scientific and Industrial Research, New Delhi for financial assistance under the R.A. scheme.

\section{REFERENCES}

Anderson JA, Churchill GA, Austrique JE, Tanskley SD, Sorells ME. (1992). Optimizing parental selection for genetic linkage map. Genome 36:181-186.

Brondani C, Brondani RP, Rangel PH, Ferreira ME (2001). Development and mapping of Oryza glumaepatula-derived microsatellite markers in the interspecific cross Oryza glumaepatula $\mathrm{x}$ O. sativa. Hereditas 134: 59-71.

Brondani RP, Brondani C, Grattapaglia D (2002). Towards a genuswide reference linkage map for Eucalyptus based exclusively on highly informative microsatellite markers. Mol. Genet. Genomics. 267:338-347.

Cantini C, Lezzoni, AF, Boritzki M, Struss D (2001). DNA fingerprinting of tetraploid cherry germplasm using simple sequence repeats. J. Am. Soc. Hortic. Sci. 126:205-209.

Cordeiro GM, Casu, R, McIntyre CL, Manners JM, Henry, RJ (2001). Microsatellite markers from sugarcane (Saccharum spp) ESTs cross transferable to ailanthus and sorghum. Plant Sci.160:1115-1123.

Deutech C, Seiter J, Petronelli P, Joly HI, Jarne P (2002). Evidence of gene flow in a geotropically clustered tree species in two rainforest stands of French Guiana. Mol. Ecol. 11:725-738.

Doyle JJ, Doyle JL (1990). Isolation of plant DNA from fresh tissue. Focus 12:13-15.

Eustoup A, Taillieez C, Cornuet JM, Solignac M (1995). Size homoplasy and mutational processes of interrupted microsatellites in two bee species, Apies mellifera and Bombus terrestris (Apidae). Mol. Biol. Evol. 12:1074-1084.

Faria M, Magalhaes AR, Ferreira MA, Meredith CP, Monterio FF (2000). Vitis vinifera must must varietal authentication using microsatellite DNA analysis (SSR). J. Agric. Food Chem. 48:10961100.

Field D, Wills C (1996). Long polymorphic microsatellites in simple organisms.

Proc. Roy. Soc. Lond. 263:209-215.

Glaubitz JC, Emebiri LC, Moran GF (2001) Dinucleotide microsatellites from

Eucalyptus sieberi: inheritance, diversity, and improved scoring of single-base differences. Genome 44:1041-1045.

Goldstein DB., Clark AG. (1995) Microsatellite variation in North American population of Drosophila melanogastor. Nucleic Acid Res., 23:3882-3886.http://www.americanbamboo.org.- American Bamboo Soc. USA.

Hartl DL, Clark AG (1989). Principles of population genetics. $2^{\text {nd }}$ edition. Sinauer Associates., MA, USA

Jakupiak JP, Wells RD (1999).Genetic instabilities in (CTG.CAG) repeats occur by recombination. J. Biol. Chem. 274: 23468-23479.

Kim NS, Armstrong KC, Fedak G, Ho K, Park NI. (2002) A microsatellite sequence from the rice blast fungus (Magnaporthe grisea) distinguishes between the centromeres of Hordeum vulgare and $H$. bulbosum in hybrid plants. Genome 4:165-174.

Kisuki S, Isagi, Y (2002). Microsatellite genetic variation in small and isolated populations of Magnolia sieboldii ssp.japonica. Heredity 88:313-321. 
Kisuki S, Isagi, Y (2002). Microsatellite genetic variation in small and isolated populations of Magnolia sieboldii ssp.japonica. Heredity 88:313-321.

Li CD, Rossanagel BG, Seoles GJ. (2000). The development of oat microsatellite markers and their use in identifying relationships among Avena species and cultivars. Theory, Appl. Genet. 101:12591268.

Lefort F, Kyvelos CJ, Zervou M, Edwards KJ, Angelakis KA (2002) Characterization of new microsatelliteloci from Vitis vinefera and their conservation in some Vitis species and hybrids. Mol. Ecol. Notes 2:20-21.

Liu DC, Gao MQ, Guan RX, Li RZ, Cao SH, Guo XL, Zhang AM (2002) Mapping quantitative trait loci for plant height in wheat (Triticum aestivum L.) using a F2:3 population. Yi Chuan Xue Bao, 29: 706-711.

Marinoni D, Akkak A, Bouhous G, Edwards KJ, Botta R (2003). Development and characterization of microsatellite markers in Castanea sativa (Mill.). Mol. Breed. 11:127-136.

McCouch SR, Chen X, Panaund O, Temnykh S, Xu Y, Cho, YG, Hunang N, Ishii T, Blair M (1997). Microsatellite marker development, mapping and application in rice genetics and breeding Plant Mol. Biol. 35:89-99.

Mariette S, Le Corre V, Austerlitz F, Kremer A. (2002). Sampling within the genome for measuring within-population diversity: trade-offs between markers. Mol. Ecol. 11:1145-1156.

Morgante M, Hanafey M, Powell W (2002) Microsatellites are preferentially associated with non-repetative DNA in plant genomes. Nature Genetics 30:194 -200.

Nei M (1987). Molecular Evolutionary Genetics Columbia University press, New York.

Paniego N, Echaide M, Munoz M, Fernandez L, Torales S, Faccio P Fuxan I, Carrera M, Zandomeni R, Suarez EY, Hopp HE. (2002) Microsatellite isolation and characterization in sunflower (Helianthus annuus L.). Genome 45:34-43.

Ramsay L, Macaulay M, Cardle L, Degli Ivanissevich S, Maestri E, Powell W Waugh R (1999) Intimate association of microsatellite repeats with retotransposons and other dispersed repetitive elements in barley. Plant Jour. 17:415-425.

Ramsay L, Macauley M, Ivanissevich SD, Maclean K, Cardle L, Fuller J, Edwards S, Tuvesson S, Morgante M, Massari A, Maestri E, Marmiroli N, Sjakste T, Gana IM, Powell W, Waugh R (2000). A simple sequence repeat-based linkage map of barley. Genetics 156:1997-2005.

Richards RI, Sutherland GR (1994). Simple repeat DNA is not replicated simply. Nature Genetics 6:114-116.
Riesner DG, Steger RZ, Owens RA, Wagenhofer M, Hillen W, Vollbach S, Henko K (1989). Temperature-gradient gel electrophoresis of nucleic acids: analysis of conformational transition, sequence variations and protein nucleic acid interactions. Electrophoresis, 10:377-389.

Sambrook J, Fritsch EF, Maniatis T (1989). Molecular Cloning: a Laboratory Manual, $2^{\text {nd }}$ Edition. Cold Spring Harbor Laboratory Press, New York.

Schlötterer C, Tautz D (1992). Slippage synthesis of simple sequence repeats. Nucl. Acid Res. 20:211-216.

Schug MD, Mackay TFC, Aquadro CF (1997) Low mutation rates of microsatellite loci in Drosophilla melanogaster. Nature Genet. 15:99102.

Sharopova N, McMullen MD, Schultz L, Schroeder S, Sanchez-Villeda H, Gardiner J, Bergstorm D, Houchins K, Melia Hancock S, Musket T, Duru N, Polacco M, Edwards K, Ruff T, Register JC, Brouwer C, Thompson R, Velasco R, Chin E, Lee M, Woodman-Clikeman W, Long MJ, Liscum E, Cone K, Davis G, Coe EH Jr (2002). Development and mapping of SSR markers for maize. Plant Mol. Biol. 48:463-81.

Tautz D, Schlötterer C (1994). Simple sequences. Curr. Opinion Genetics and Development 4:832-837.

Wright S. (1978) Variability within and among natural populations. Vol 4. The University of Chicago Press, Chicago.

Xie CJ, Ni ZF, Sun QX, Yang ZM, Liu BS, Wei YL (2001). Molecular tagging of a major powdery mildew resistance gene MIG in wheat derived from wild Emmer by using microsatellite markers. Yi Chuan Xue Bao, 28:1034-1039.

Xin X, Mei UP, Zhian F, Xiping XU (2002). The direction of microsatellite mutation is dependent upon repeat length. Nature Genetics 24:396399.

Zane L, Bargelloni L, Patarnello T (2002) Strategies for microsatellite isolation- a review. Mol. Ecol.11:1-16.

Zhu Y, Queller DC, Strassman JE (2000) A phylogenetic perspective on sequence evolution in microsatellite loci. J. Mol. Evol. 50:324338 